\title{
PREVALENCE AND OUTCOMES OF ACUTE HEPATITIS A INFECTION IN BENHA FEVER HOSPITAL PATIENTS
}

\author{
By
Sameh M. Abd El-Latif, Amgad El-Zahaby, and Mohamed M. Abd El- Halim

Hepato-Gastroenterology and Infectious Diseases Department, Al-Azhar University

(Cairo)

E-mail: drsamehtiger0@gmail.com

\begin{abstract}
Background: To what extent has hepatitis A virus become widespread among the patients of Benha Fever Hospital and what are the complications it causes? What procedures have been taken to control the level of infection? Inventory of the symptoms that appeared on patients between 2016 and 2019.

Aim of the research: To study the prevalence of hepatitis A among Benha Fever Hospital patients, the apparent symptoms, and the complication rate for some cases.

Patients and methods: This study was carried out in cooperation between the Hepato-gastroenterology and Infectious Diseases Department, Al-Azhar University, Cairo, and Benha Fever Hospital from January 2016 to December 2019. The study included 3132 patients with HAV infection in Benha Fever Hospital by studying the apparent symptoms and the analytical results and comparing the results and symptoms of the patients and the fates. (Hospital stay and mortality for whole study group, and relation between mortality and year incidence).

Results: By the observation of the diagnosis of Hepatitis A virus it's concluded that $97.3 \%$ of patients didn't suffer from complications of HAV and about $2.7 \%$ of patients Their health deteriorated and they suffered complications classified as follow: $0.8 \%$ of patients suffer from encephalopathy, $0.2 \%$ suffered sepsis, $0.5 \%$ had pancreatitis, $0.9 \%$ had gastrointestinal bleeding, $0.2 \%$ had acute renal failure, $0.1 \%$ had aplastic anemia, $0.1 \%$ had seizures. In 2016 was the lowest percentage of HAV infection with (16.4\%), but 2018 was the highest percentage of HAV infection with (39.2\%). This demonstrates a lack of awareness and late detection of the disease year by year.
\end{abstract}

Conclusion: HAV infection imparts lifelong immunity and can induce symptoms ranging from asymptomatic to fulminant hepatic failure, which can lead to death in certain cases. HAV infections have a fatality rate of less than 1.2 percent.

Keywords: Fulminant hepatitis, abdominal pain, Jaundice, ALF, HAV.

\section{INTRODUCTION}

Acute hepatitis A virus (HAV) infection is a common cause of ALF in the third world and emerging countries but also has been recorded as a substantial cause in developed countries. The risk of developing ALF in children with acute hepatitis $\mathrm{A}$ is low, estimated to be $1-2 \%$ of all affected patients, but the mortality is higher in patients 50 years of age and older and in those younger than 5 years of age. In patients with fulminant hepatic failure due to hepatitis A virus (HAV), survival rates are greater than $50-60 \%$. These patients account for (10-20\%) of 
pediatric liver transplantation. The highest levels of hepatitis A virus are present in feces from 1-2 weeks before the onset of symptoms until about 7 days after the patient becomes jaundiced (third week of illness) (Koenig, 2017).

The virus is detectable in the stool and blood during the symptomatic phase of infection; this means that the individual is infectious during this phase and at risk of transmitting the virus to others. Transmission occurs through the personto-person spread, primarily via an orofecal route. The incubation period for hepatitis A ranges from 15-45 days (mean 28 days). The illness is usually self-limited, and the severity is age-dependent. In infants and preschool-age children, acute hepatitis A may be clinically in apparent. Signs and symptoms typically resolve within 2 months, though $10-15 \%$ of symptomatic persons have a relapsing or prolonged course lasting up to 9 months. The clinical course of HAV infection varies greatly, ranging from asymptomatic, subclinical infections to cholestatic hepatitis or fulminant liver failure (Webb, 2020).

\section{PATIENTS AND METHODS}

This study is a cross-section study that will be conducted on patients with a confirmed diagnosis of acute hepatitis A at Benha Fever Hospital starting from January 2016 till June 2018.

\section{Inclusion criteria}

Patients at different age groups who present with clinical symptoms and signs suggestive of acute hepatitis with raised liver enzymes (ALT, AST) and bilirubin level and the diagnosis of acute hepatitis A was confirmed by the presence of HAV IgM Antibody hepatitis marker.

\section{Exclusion criteria}

HAV accompanied with other hepatitis viruses.

\section{A. Clinical Examination:}

Thorough history taking stressing on (Demographic data (age, sex, residence), Duration of illness. Medical history, Developmental history, and family history).

Complete clinical examination such as Abdominal examination with special emphasis on the size, consistency of liver, presence of splenomegaly and ascites, Staging of hepatic encephalopathy if present (West Haven Staging).

\section{B. Investigations:}

Initial laboratory investigations including:

\section{Complete blood picture.}

- Total, direct serum bilirubin

- Serum aminotransferases (alanine aminotransferase (ALT), Aspartate aminotransferase (AST), and Alkaline phosphatase.

- Prothrombin time, international normalized ratio (INR).

- Serum protein, serum albumin.

- Blood glucose level.

- Serum ammonia, Urea, and Creatinine.

- Specific investigation to determine the cause of acute Hepatitis A and rule out associated liver diseases:

- Anti HAV IgM.

- HBs Ag and H Core Ab.

- HCV Ab. 


\section{Imaging Investigations:}

Abdominal ultrasonography stressing liver size, echogenicity, size of the spleen, and presence of ascites.

Computed Tomography of the brain in suspected cases of hepatic encephalopathy stressing on brain edema and other abnormalities as subdural hematoma or intracranial bleeding.

\section{Presence of complications:}

(Encephalopathy, cerebral edema, coagulopathy, renal failure, and prolonged cholestasis) and the measure of treating these complications.

E. prognosis: cured, complications and death.

\section{Diagnosis}

Cases of hepatitis A are not clinically distinguishable from other types of acute viral hepatitis. Specific diagnosis is made by the detection of HAV-specific Immunoglobulin $\mathrm{G}(\operatorname{IgM})$ antibodies in the blood. Additional tests include reverse transcriptase-polymerase chain reaction (RT-PCR) to detect the hepatitis A virus RNA and may require specialized laboratory facilities (Nainan, Xia. 2016).

\section{Molecular diagnosis:}

Molecular methods provide tools for studying HAV infection; the amplification of HAV RNA by reverse transcription, followed by PCR of the CDNA, is the most sensitive technique for screening clinical specimens. Studies using reverse transcription PCR (RT-PCR) have demonstrated that HAV RNA can be detected in blood earlier than antibodies and that the viremia may be present for a much longer period during the convalescent phase of hepatitis A than was previously thought. The efficiency of extraction methods for HAV RNA in clinical samples is very important for molecular diagnosis. Studies have shown that the detection of HAV RNA by nested PCR is clinically effective for the diagnosis of HAV infection (Koff. 2012).

Amplification of viral RNA by nested PCR is currently the most sensitive and widely used method for the detection of HAV RNA in different types of samples (serum, plasma, saliva, fecal suspension, and environmental samples). Although high HAV viral load can be present in stool samples, the detection, quantification, and genotyping of HAV RNA are carried out primarily in serum samples, owing to the presence of inhibitors in feces that can interfere with the detection of HAV genetic material, such as bile salts, hemoglobin degradation products and complex polysaccharides that can interfere with the enzyme system used for amplification (Jenkins, Minhas. 2018).

Studies show that the PCR detection of HAV RNA has an important role in the early diagnosis of infection, especially in the window period during outbreaks and in cases of acute hepatitis with unknown etiology. Detection of HAV RNA before IgM anti-HAV seroconversion may be used as an early diagnosis method during hepatitis A outbreaks. HAV RNA testing can also help elucidate acute hepatitis cases of unknown etiology. The molecular diagnosis of hepatitis $\mathrm{A}$ is not used in clinical laboratories and blood banks, as is currently done for $\mathrm{HIV}, \mathrm{HBV}$, and $\mathrm{HCV}$ infections (Koff. 2012). 
The diagnostic for hepatitis $\mathrm{A}$ is usually only performed with the detection of antibodies, while the detection of HAV RNA and the quantification of the viral load are rarely used in routine laboratories for diagnosis. However, the detection and quantification of HAV RNA are important to the diagnosis of patients without specific antibodies for hepatitis A and the monitoring of infection in exceptional cases or research work concerning HAV (Bower, Nainan. 2010).

\section{Hepatitis A IgG/IgM:}

Hepatitis A is a highly contagious liver infection caused by the hepatitis A virus (HAV). When the body is infected with HAV, it defends itself by producing two types of antibodies in sequence: first, IgM, which appears 2 to 4 weeks after infection and is present for 2 to 6 months, then $\mathrm{IgG}$, which appears a few weeks after IgM and is present for the rest of the person's life. IgG provides long-term immunity (protection), whether due to a prior infection by the virus or due to vaccination. Testing for HAV antibodies Total (IgG plus IgM) is especially useful in confirming an individual's long-term immunity and the appropriateness of vaccination. The specific anti-HAV IgM test is used mainly to find the cause of acute or very recent liver disease (Gowland P., Fontana S, 2014).

A positive HAV-Ab total test (without isolated testing for $\operatorname{IgM}$ ) indicates prior HAV exposure but does not rule out acute or very recent hepatitis. About $30 \%$ of adults over the age of 40 are positive for HAV-Ab total. A negative HAV Ab Total test means there has been no prior exposure to the virus and the hepatitis $\mathrm{A}$ vaccination should be administered. A positive $\operatorname{IgM}$ test suggests acute or very recent hepatitis A (Gowland, Fontana. 2014).

\section{Statistical analysis of the data:}

Data were fed to the computer using IBM SPSS software package version 20.0.

Qualitative data were described using numbers and percentages. Comparison between different groups regarding categorical variables was tested using the Chi-square test. When more than $20 \%$ of the cells have an expected count less than 5 , correction for chi-square was conducted using Firsher's exact test or Monte Carlo correction.

The distributions of quantitative variables were tested for normality using the Shapiro-Wilk test and D'Agstino test, also Histogram and QQ plot were used for vision test. If it reveals normal data distribution, parametric tests were applied. If the data were abnormally distributed, non-parametric tests were used.

Quantitative data were described using mean and standard deviation for normally distributed data while abnormally distributed data were expressed using median, minimum, and maximum.

For normally distributed data, comparisons between two independent populations were done using an independent t-test.

For abnormally distributed data, MannWhitney Test (for data distribution that was significantly deviated from normal) was used to analyze two independent populations.

Significance test results are quoted as two-tailed probabilities. The significance 
of the obtained results was judged at the $5 \%$ level.

\section{Data Management and Analysis:}

The collected data was revised, coded, tabulated, and introduced to a PC using Statistical Package for Social Science (SPSS 25); Mean, Standard deviation ( \pm SD) and range for parametric numerical data, while Median and Interquartile range (IQR) for non-parametric numerical data, Frequency and percentage of non- numerical data, Student T-Test was used to assess the statistical significance of the difference between two study group means, Chi-Square test was used to examine the relationship between two qualitative variables, Fisher's exact test was used to examine the relationship between two qualitative variables when the expected count is less than 5 in more than $20 \%$ of cells.

\section{RESULTS}

After revising data, coding and analyzing it, it is collected in tables to be presented for the prevalence of HAV between the patients of Benha fever hospital according to their sex, residence, complains, risk factors they had, complications they had been developed to and mortality rate and according to year of incidence. The collected tables are shown as below:

\begin{tabular}{|c|c|c|c|}
\hline table & & $\mathrm{N}$ & events \\
\hline \multirow{3}{*}{ year } & 2016 & 514 & 16.4 \\
\cline { 2 - 4 } & 2017 & 721 & 23 \\
\cline { 2 - 4 } & 2018 & 1227 & 39.2 \\
\cline { 2 - 4 } & 2019 & 670 & 21.4 \\
\hline \multirow{2}{*}{ sex } & male & 2004 & 64 \\
\cline { 2 - 4 } & female & 1128 & 36 \\
\hline \multirow{2}{*}{ residence } & Urban & 1885 & 60.2 \\
\cline { 2 - 4 } & Rural & 1247 & 39.8 \\
\hline
\end{tabular}

\begin{tabular}{|c|c|c|c|}
\hline \multicolumn{2}{|c|}{} & Frequency & Percent \\
\hline \multirow{4}{*}{ complain } & abdominal pain & 995 & 31.8 \\
\cline { 2 - 4 } & vomiting and diarrhea & 935 & 29.9 \\
\cline { 2 - 4 } & dark urine & 621 & 19.8 \\
\cline { 2 - 4 } & yellowish discoloration of sclera & 554 & 17.7 \\
\cline { 2 - 4 } & hematemesis and melena & 27 & .9 \\
\cline { 2 - 4 } & Total & 3132 & 100.0 \\
\hline
\end{tabular}

This table shows the number of infected people according to the complains (abdominal pain, vomiting and diarrhea, dark urine, yellowish discoloration of sclera, hematemesis and melena). 
SAMEH M. ABD EL-LATIF et al.,

Complications

\begin{tabular}{|c|c|c|c|}
\hline \multicolumn{2}{|c|}{ No } & Frequency & Percent \\
\hline \multirow{7}{*}{ Valid } & 3047 & 97.3 \\
\cline { 2 - 4 } & encephalopathy & 29 & .9 \\
\cline { 2 - 4 } & sepsis & 6 & .2 \\
\cline { 2 - 4 } & pancreatitis & 13 & .4 \\
\cline { 2 - 4 } & gastrointestinal bleeding & 16 & .5 \\
\cline { 2 - 4 } & acute renal failure & 7 & .2 \\
\cline { 2 - 4 } & aplastic anemia & 3 & .1 \\
\cline { 2 - 4 } & seizures & 3 & .1 \\
\cline { 2 - 4 } & Hematemesis and melena & 8 & .3 \\
\cline { 2 - 4 } & Total & 3132 & 100.0 \\
\hline
\end{tabular}

This table shows the number of infected people according to their complication (encephalopathy, sepsis, pancreatitis, gastrointestinal bleeding, acute renal failure, aplastic anemia, seizures).

Risk factor

\begin{tabular}{|c|c|c|c|}
\hline \multicolumn{2}{|c|}{} & Frequency & Percent \\
\hline \multirow{4}{*}{} & no & 2972 & 94.9 \\
\cline { 2 - 4 } & DM & 72 & 2.3 \\
\cline { 2 - 4 } & Pregnancy & 53 & 1.7 \\
\cline { 2 - 4 } & DM + Pregnancy & 4 & .1 \\
\cline { 2 - 4 } & Chronic renal failure & 25 & .8 \\
\cline { 2 - 4 } & Chronic RF + DM & 2 & .1 \\
\cline { 2 - 4 } & Breast cancer & 1 & .0 \\
\cline { 2 - 4 } & Leukemia & 2 & .1 \\
\cline { 2 - 4 } & Non-Hodgkin lymphoma & 1 & .0 \\
\cline { 2 - 4 } & Total & 3132 & 100.0 \\
\hline
\end{tabular}

This table shows the number of infected people according to the risk factors they have (DM, pregnancy, chronic renal failure, breast cancer, leukemia, non-Hodgkin lymphoma).

\section{Mortality}

\begin{tabular}{|c|c|c|c|}
\hline \multicolumn{2}{|c|}{} & Frequency & Percent \\
\hline \multirow{3}{*}{ Valid } & No & 3095 & 98.8 \\
\cline { 2 - 4 } & Yes & 37 & 1.2 \\
\cline { 2 - 4 } & Total & 3132 & 100.0 \\
\hline
\end{tabular}

This table shows the mortality frequency and mortality rate. 
Complain, complication crosstab

\begin{tabular}{|c|c|c|c|c|c|}
\hline & \multicolumn{2}{|c|}{ complications } & \multirow{2}{*}{ Total } \\
\hline & & & No & Yes & \\
\hline \multirow{10}{*}{ complain } & \multirow{2}{*}{ abdominal pain } & Count & 990 & 5 & 995 \\
\hline & & $\%$ Within complain & $99.5 \%$ & $0.5 \%$ & $100.0 \%$ \\
\hline & \multirow{2}{*}{ vomiting and diarrhea } & Count & 931 & 4 & 935 \\
\hline & & $\%$ Within complain & $99.6 \%$ & $0.4 \%$ & $100.0 \%$ \\
\hline & \multirow{2}{*}{ dark urine } & Count & 572 & 49 & 621 \\
\hline & & \% Within complain & $92.1 \%$ & $7.9 \%$ & $100.0 \%$ \\
\hline & \multirow{2}{*}{$\begin{array}{l}\text { yellowish discoloration of } \\
\text { sclera }\end{array}$} & Count & 554 & 0 & 554 \\
\hline & & \% Within complain & $100.0 \%$ & $0.0 \%$ & $100.0 \%$ \\
\hline & \multirow{2}{*}{ hematemesis and melena } & Count & 0 & 27 & 27 \\
\hline & & $\%$ Within complain & $0.0 \%$ & $100.0 \%$ & $100.0 \%$ \\
\hline \multirow{2}{*}{\multicolumn{2}{|c|}{ Total }} & Count & 3047 & 85 & 3132 \\
\hline & & \% Within complain & $97.3 \%$ & $2.7 \%$ & $100.0 \%$ \\
\hline
\end{tabular}

This table shows the relationship between complains and complications (count \& rate).

Presence of Risk Factors, complications Crosstabulation

\begin{tabular}{|c|c|c|c|c|c|}
\hline & \multicolumn{2}{|c|}{ complications } & \multirow{2}{*}{ Total } \\
\hline & & & No & Yes & \\
\hline \multirow{4}{*}{$\begin{array}{l}\text { Presence of Risk } \\
\text { Factors }\end{array}$} & \multirow[b]{2}{*}{ No } & Count & 2925 & 47 & 2972 \\
\hline & & $\begin{array}{c}\% \text { Within Presence of } \\
\text { Risk Factors }\end{array}$ & $98.4 \%$ & $1.6 \%$ & $100.0 \%$ \\
\hline & \multirow[b]{2}{*}{ Yes } & Count & 122 & 38 & 160 \\
\hline & & $\begin{array}{c}\text { \% Within Presence of } \\
\text { Risk Factors }\end{array}$ & $76.3 \%$ & $23.8 \%$ & $100.0 \%$ \\
\hline \multirow{2}{*}{\multicolumn{2}{|c|}{ Total }} & Count & 3047 & 85 & 3132 \\
\hline & & $\begin{array}{c}\% \text { Within Presence of } \\
\text { Risk Factors }\end{array}$ & $97.3 \%$ & $2.7 \%$ & $100.0 \%$ \\
\hline
\end{tabular}

This table shows the relationship between presence of risk factors and complications (count \& rate).

Complain, mortality Crosstab

\begin{tabular}{|c|c|c|c|c|c|}
\hline & \multicolumn{2}{|c|}{ Mortality } & \multirow{2}{*}{ Total } \\
\hline & & & No & Yes & \\
\hline \multirow{10}{*}{ complain } & \multirow{2}{*}{ abdominal pain } & Count & 989 & 6 & 995 \\
\hline & & \% within complain & $99.4 \%$ & $0.6 \%$ & $100.0 \%$ \\
\hline & \multirow{2}{*}{ vomitting and diarhea } & Count & 930 & 5 & 935 \\
\hline & & \% within complain & $99.5 \%$ & $0.5 \%$ & $100.0 \%$ \\
\hline & \multirow{2}{*}{ dark urine } & Count & 603 & 18 & 621 \\
\hline & & \% within complain & $97.1 \%$ & $2.9 \%$ & $100.0 \%$ \\
\hline & \multirow{2}{*}{ yellowish discoloration of sclera } & Count & 548 & 6 & 554 \\
\hline & & \% within complain & $98.9 \%$ & $1.1 \%$ & $100.0 \%$ \\
\hline & \multirow{2}{*}{ hematemesis and melena } & Count & 25 & 2 & 27 \\
\hline & & \% within complain & $92.6 \%$ & $7.4 \%$ & $100.0 \%$ \\
\hline \multirow{2}{*}{\multicolumn{2}{|c|}{ Total }} & Count & 3095 & 37 & 3132 \\
\hline & & \% within complain & $98.8 \%$ & $1.2 \%$ & $100.0 \%$ \\
\hline
\end{tabular}

This table shows the relationship between complains and presence of mortality (count $\&$ rate). 


\section{DISCUSSION}

HAV is a member of the family Picornaviridae and was initially placed in the genus Enterovirus. However, a further study demonstrated that the virus was sufficiently different from other picornaviruses to be classified within its genus, Hepatic virus. HAV is one of nine species of Hepatic virus and the only one known to infect humans. There are six genotypes of HAV, three that infect humans and three affecting simians, but only one serotype. The remaining members of the genus infect a range of species, including bats, hedgehogs, shrews, and rodents. Phylogenetic analysis suggests that the genus originated in small mammals and that human HAV has a rodent origin, although a zoonotic reservoir no longer exists (Webb, Kelly. 2020).

HAV is non-enveloped icosahedral viruses. The lack of a lipid envelope offers the virus a significant advantage in terms of its ability to spread in the environment, as demonstrated by the foodborne and waterborne outbreaks, which are synonymous with hepatitis A. This is because a stable, naked protein capsid offers the fragile RNA genome significant protection against harsh environmental conditions. In comparison, the transmission of enveloped virus tends to require at least close contact between individuals, if not the exchange of bodily fluids. This is because the viral envelope contains virus-encoded glycoproteins called peplomers, which mediate interactions with cell surface receptors. Without these peplomers, the virion is unable to gain access to a host cell, so it is vulnerable to anything that would disrupt the lipid bilayer, such as drying, solvents, or detergents. Within a host, however, enveloped viruses have several advantages over naked virions. The envelope facilitates crossing the plasma membrane, allowing new virions to leave the cell without the need for cell lysis, and also protects the virus from the immune response by hiding antigens from neutralizing antibodies (Nelson, Weng. 2020).

There is a significant body of evidence that suggests that although HAV and is a non-enveloped virus, they can also enjoy at least some of the benefits of enveloped viruses. HAV virions, which are shed in the stool, are naked protein capsids, ideally suited to their role of reaching new hosts across both time and distance in a potentially hostile environment. However, $\mathrm{HAV}$, which is isolated from the serum of individuals suffering an acute infection, is wrapped in a hijacked layer of the host cell membrane, similar to those found on classical enveloped viruses but distinguished by the lack of any virusencoded proteins at the surface. This allows circulating virions to avoid the immune response, as antigenic proteins are protected from neutralizing antibodies. However, the lack of peplomers raises questions as to how these quasi-enveloped virions achieve entrance into host cells (Brundage, \& Fitzpatrick. 2016).

The World Health Organization estimates that there are 1.4 million cases of hepatitis A globally each year, resulting in approximately 7,000 deaths. The primary route of transmission for HAV is fecal-oral, primarily through direct person-to-person contact, but also via contaminated food or water. Men who 
have sex with men are at increased risk of infection, as are any persons engaging in oral-anal sexual contact regardless of gender or sexual orientation. Parenteral transmission via contaminated blood products has been described, and injecting drug users are at high risk, with increased prevalence positively correlated with low incomes. Infected individuals shed virus in their stool for around 2 weeks before becoming symptomatic and typically for a few days after but may continue to do so for several weeks. Even with good standards of hygiene and sanitation facilities, the rate of infection in close contacts of cases is high, suggesting very efficient interpersonal transmission (Nelson, Weng. 2020).

The rate and pattern of HAV transmission vary widely between different parts of the world, primarily determined by socioeconomic factors. In regions with smaller family sizes, better sanitation facilities, and greater access to clean drinking water, rates of infection are lower. Counter intuitively, lower rates of transmission do not equate to less disease. In resource-poor areas of high endemicity, such as Africa, parts of Asia, and South America, infection with HAV in early childhood is widespread. In most cases, young children are asymptomatic or experience a very mild illness, and HAV infection typically confers lifelong immunity. Conversely, in high-income regions of low endemicity, like North America, Western Europe, Japan, and Australia, exposure in childhood is rarer. As a result, a much smaller proportion of the adult population has anti-HAV antibodies. If HAV is introduced, significant outbreaks can result, particularly in high-risk groups, such as men who have sex with men, homeless people, and recreational drug users. These outbreaks primarily affect adolescents and adults, who are more susceptible to becoming seriously ill. Over the past few decades, improvements in hygiene and sanitation in some low- and middleincome countries have reduced HAV transmission and increased the average age at infection. This "epidemiological transition" shifts the epidemiological pattern closer to that seen in industrialized nations, producing a paradoxical increase in both morbidity and mortality associated with hepatitis A (Webb, Kelly. 2018).

Hepatitis A is a vaccine-preventable, communicable disease of the liver caused by the hepatitis A virus (HAV). It is usually transmitted person-to-person through the fecal-oral route or consumption of contaminated food or water.

Hepatitis $\mathbf{A}$ is a self-limited disease that does not result in chronic infection. Most adults with hepatitis A have symptoms, including fatigue, low appetite, stomach pain, nausea, and jaundice, that usually resolve within 2 months of infection; most children less than 6 years of age do not have symptoms or have an unrecognized infection.

Antibodies produced in response to hepatitis A infection last for life and protect against reinfection. The best way to prevent hepatitis A infection is to get vaccinated.

Acute hepatitis A virus (HAV) infection is a common cause of ALF in the third world and emerging countries but also has been recorded as a substantial cause in developed countries (Linder, \& Malani. 2017). 
The risk of developing ALF in children with acute hepatitis A is low, estimated to be $1-2 \%$ of all affected patients, but the mortality is higher in patients 50 years of age and older and in those younger than 5 years of age.

In patients with fulminant hepatic failure due to hepatitis A virus (HAV), survival rates are greater than $50-60 \%$. These patients account for (10-20\%) of pediatric liver transplantation (Sánchez, Bosch. 2013).

The highest levels of hepatitis A virus are present in feces from 1-2 weeks before the onset of symptoms until about 7 days after the patient becomes jaundiced (third week of illness). The virus is detectable in the stool and blood during the symptomatic phase of infection; this means that the individual is infectious during this phase and at risk of transmitting the virus to others. Transmission occurs through the personto-person spread, primarily via an orofecal route. The incubation period for hepatitis A ranges from 15-45 days (mean 28 days) (Bower, Nainan. 2010).

HAV is responsible for acute hepatitis only. Often, this is an anicteric illness, with clinical symptoms indistinguishable from other forms of viral gastroenteritis, particularly in young children. It is characteristically an acute febrile illness with an abrupt onset of anorexia, nausea, malaise, vomiting, dark urine, right upper quadrant abdominal pain, and jaundice. The typical duration of illness is 7-14 days. Other organ systems can be affected during acute HAV infection. Regional lymph nodes and the spleen may be enlarged.
The bone marrow may be moderately hypoplastic, and aplastic anemia has been reported. Small intestinal tissues may show changes in villous structure, and ulceration of the gastrointestinal tract can occur, especially in fatal cases. Acute pancreatitis and myocarditis have been reported, nephritis, arthritis, vasculitis, and cryoglobulinemia can result from circulating immune complexes (Nainan, Xia.2016).

The illness is usually self-limited, and the severity is age-dependent. In infants and preschool-age children, acute hepatitis A may be clinically in apparent. Signs and symptoms typically resolve within 2 months, though $10-15 \%$ of symptomatic persons have a relapsing or prolonged course lasting up to 9 months (Rakela, Redeker, 2012).

The diagnosis of hepatitis A relies on the detection of a specific antibody response to HAV. The presence of antiHAV IgM in the serum is indicative of a recent HAV infection. Anti-HAV IgM is present in the serum 5-10 days before the onset of symptoms and may persist for up to 6 months after infection. HAV RNA can be detected in serum and stool during acute infection by nucleic acid amplification (Rakela, Redeker, 2012).

\section{CONCLUSION}

HAV infection imparts lifelong immunity and can induce symptoms ranging from asymptomatic to fulminant hepatic failure, which can lead to death in certain cases. HAV infections, on the other hand, have a fatality rate of less than 0.1 percent, and those at increased risk are mainly young children and elderly adults with underlying chronic liver disease. 


\section{DISCLOSURE}

The authors report no conflicts of interest in this work.

\section{REFERENCES}

1. Gowland, P., Fontana, S., Niederhauser, C., \& Taleghani, B. M. (2014): Molecular and serologic tracing of a transfusion-transmitted hepatitis A virus. Transfusion, 44(11), 15551561.

2. Nainan, O. V., Xia, G., Vaughan, G., \& Margolis, H. S. (2016): Diagnosis of hepatitis A virus infection: a molecular approach. Clinical microbiology reviews, 19(1), 63-79.

3. Webb, G. W., Kelly, S., \& Dalton, H. R. (2020): Hepatitis A and Hepatitis E: Clinical and Epidemiological Features, Diagnosis, Treatment, and Prevention. Clinical Microbiology Newsletter, 42(21), 171-179.

4. Koenig, K. L., Shastry, S., \& Burns, M. J. (2017): Hepatitis A virus: essential knowledge and a novel identify-isolate-inform tool for frontline healthcare providers. Western Journal of Emergency Medicine, 18(6), 1000.

5. Brundage, S. C., \& Fitzpatrick, N. A. (2016): Hepatitis A. American family physician, 73(12), 2162-2168.

6. Nelson, N. P., Weng, M. K., Hofmeister, M. G., Moore, K. L., Doshani, M., Kamili, S., ... \& Schillie, S. (2020): Prevention of hepatitis
A virus infection in the United States: recommendations of the Advisory Committee on Immunization Practices, 2020.

7. Linder, K. A., \& Malani, P. N. (2017): Hepatitis a. Jama, 318(23), 2393-2393.

8. Sánchez, G., Bosch, A., Gómez-Mariano, G., Domingo, E., \& Pintó, R. M. (2013): Evidence for quasispecies distributions in the human hepatitis A virus genome. Virology, 315(1), 34-42.

9. Rakela, J., Redeker, A. G., Edwards, V. M., Decker, R., Overby, L. R., \& Mosley, J. W. (2012): Hepatitis A virus infection in fulminant hepatitis and chronic active hepatitis. Gastroenterology, 74(5), 879-882.

10. Bower, W. A., Nainan, O. V., Han, X., \& Margolis, H. S. (2010): Duration of viremia in hepatitis A virus infection. The Journal of infectious diseases, 182(1), 12-17.

11. Koff, R. S. (2012): Clinical manifestations and diagnosis of hepatitis A virus infection. Vaccine, 10, S15-S17.

12. Brundage, S. C., \& Fitzpatrick, N. A. (2016): Hepatitis A. American family physician, 73(12), 2162-2168.

13. Franco E, Meleleo C, Serino L, Sorbara D, Zaratti L. Hepatitis A (2012): Epidemiology and prevention in developing countries. World J Hepatol. 2012; 4(3): 68-73. doi: 10.4254/wjh.v4.i3.68. 
SAMEH M. ABD EL-LATIF et al.,

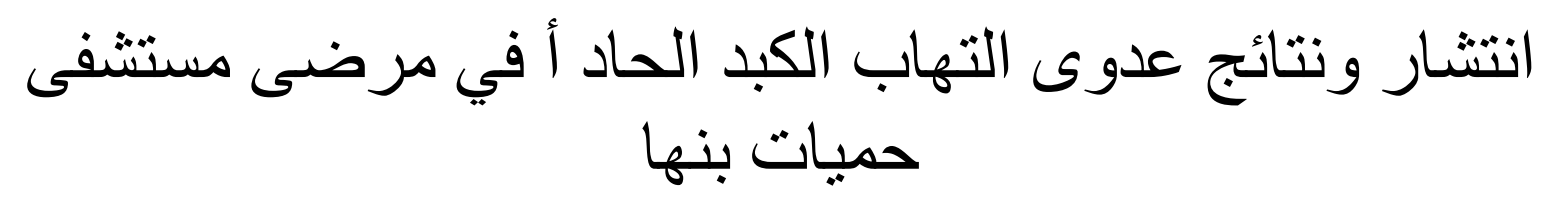

سامح محمود عبد اللطيف، أمجد الذهبي، محمد محمود

قسم الكبد والجهاز الهضمى والأمراض المعدية، كلية الطب، جامعة الأزهر، القاهرة

\section{E-mail: drsamehtiger0@gmail.com}

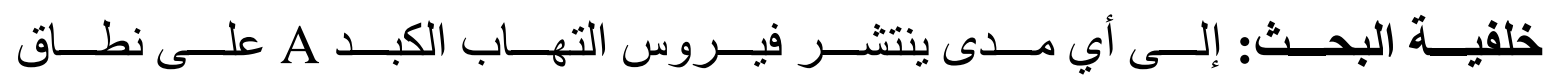

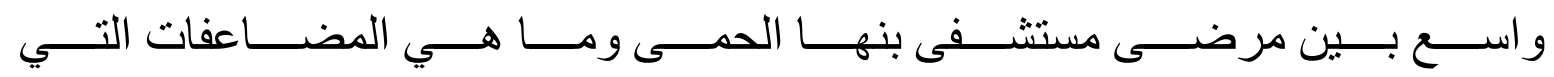

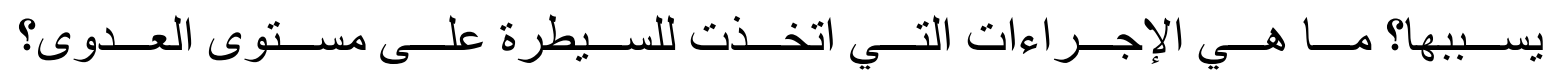
جرد الأعر اض التي ظهرت على المرضى بين عامي 2016 و 2019.

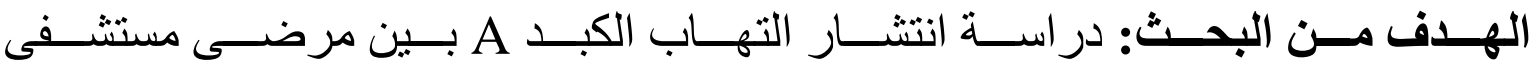
حمى بنها، و الأعر اض الظاهرة، ومعدل المضاعفات لبعض الحالات.

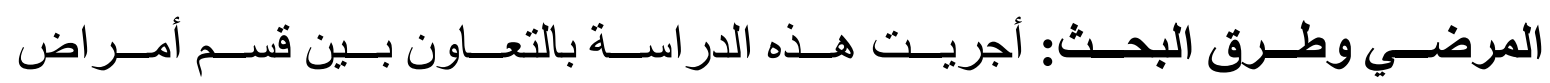

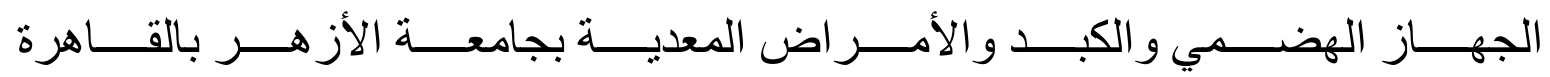

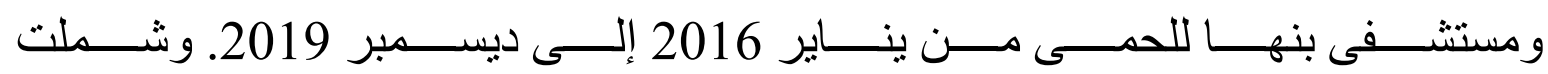

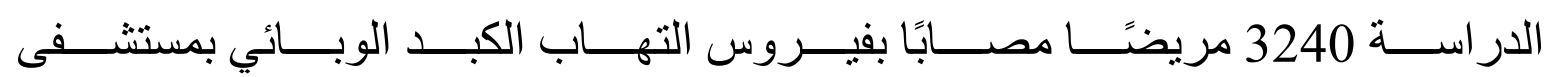

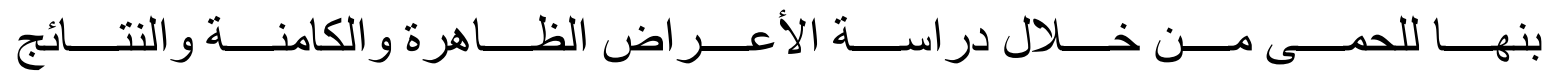

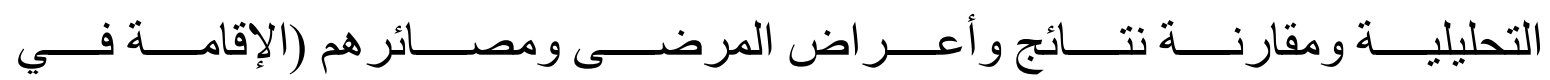

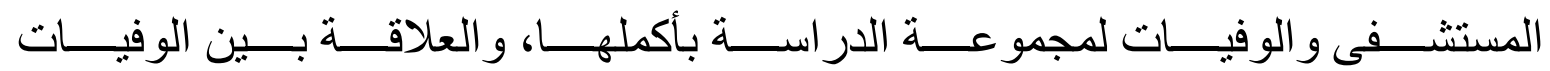
وسنة الحدوث).

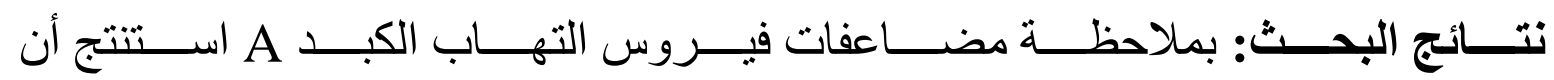

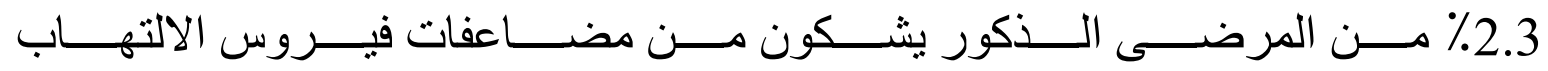

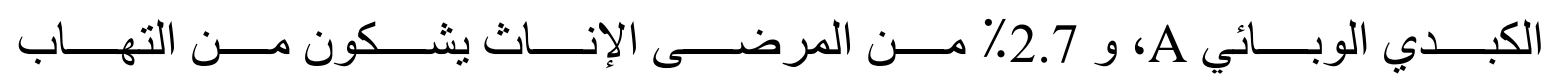

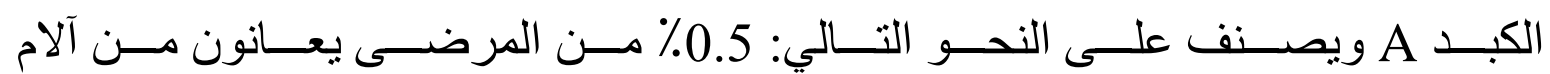


فــي الــبطن، و 0.43 يثـــكو 0\% مــن القــيء و الإســـهال، 7.89\% لــديهم بـــول

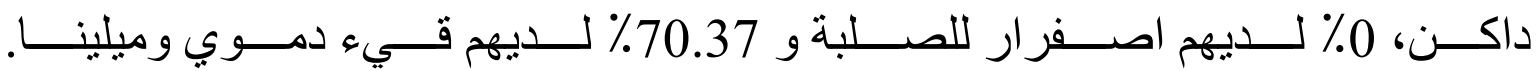

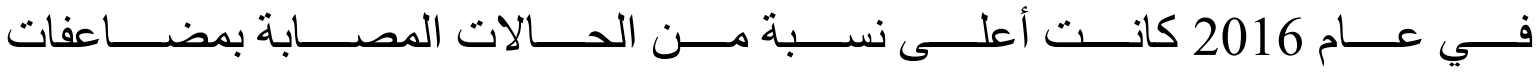

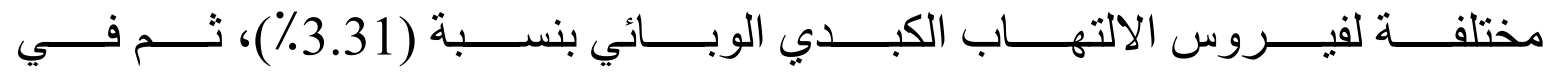

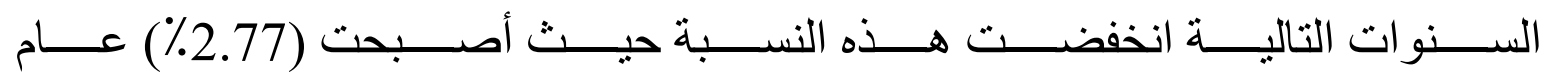

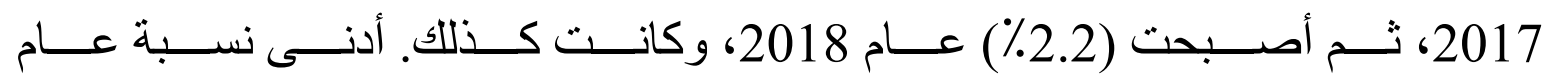

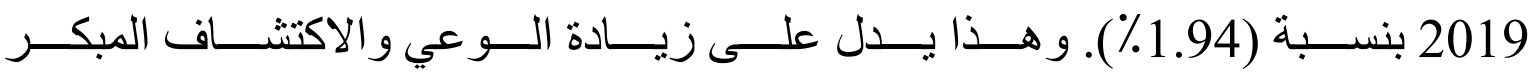
للمرض عامًا بعد عام.

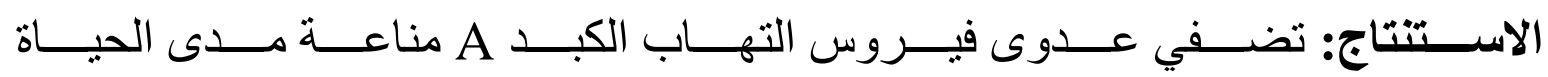

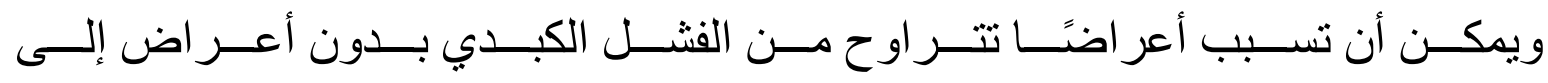

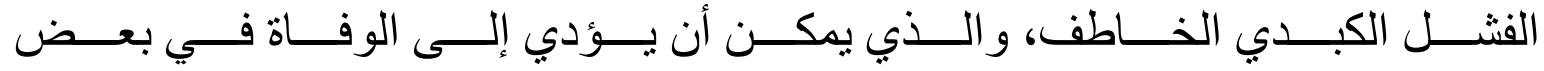

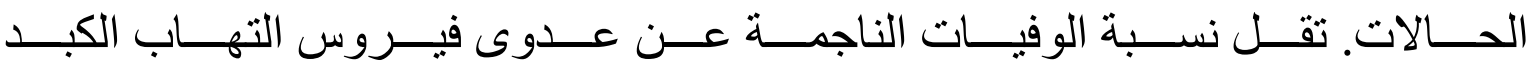
الوبائي عن 0.1 في المائة. 